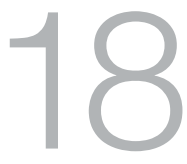

\title{
Cross-currents: Teana and Moenau, Tahitian Tourists in Seattle
}

Miriam Kahn, Teana Gooding and Moenau Holman

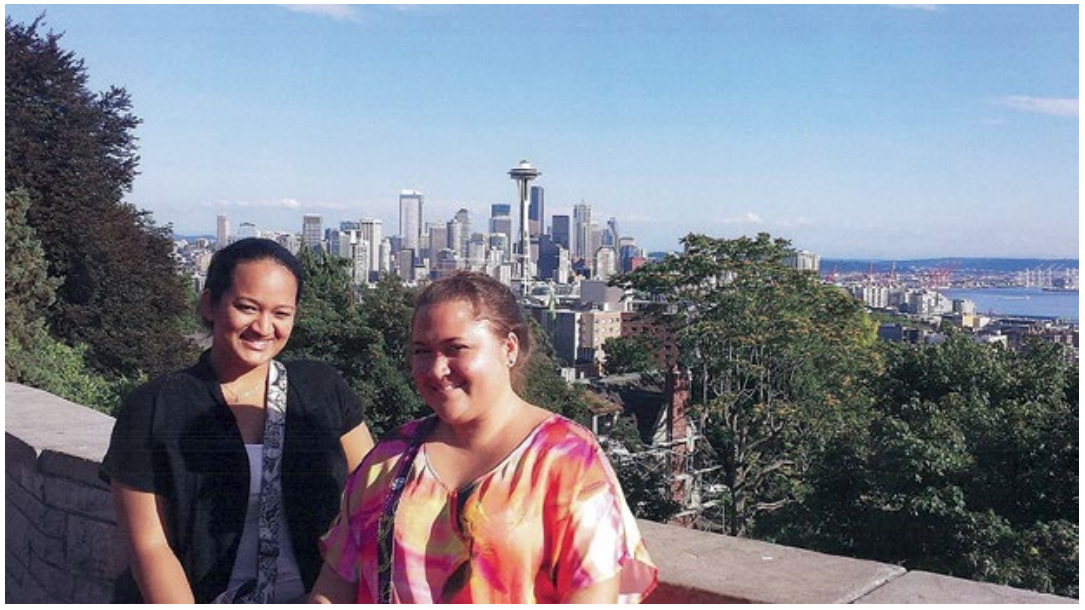

Figure 98. Moenau (left) and Teana (right) at the Kerry Park Lookout, Seattle.

Source. Photographed by Miriam Kahn, 10 August 2013. 


\section{Introduction}

\section{Miriam Kahn}

Moenau Holman and Teana Gooding, from the island of Huahine in French Polynesia, are students at the Université de la Polynésie Française, on the island of Tahiti. Moenau's area of study is social service administration and Teana's is economics.

I've known Teana since she was six years old. Her parents, Hiti and Turia, were our landlords when I began fieldwork on Huahine in 1995. We have continued to enjoy their friendship over the years, visiting with them each time I return to Huahine for my research.

In the summers of 2010 and 2012 I took a group of students from the University of Washington to Huahine for a month-long study abroad trip where students had homestays with Tahitian families. Both Moenau's and Teana's families graciously hosted some of the students (two students each summer). They became very attached to the American students, who established lasting friendships with their Tahitian hosts. Little did I know that a few months after the students left Huahine in 2012, Moenau and Teana would begin planning a big adventure to come to Seattle to visit everyone!

In January 2013, I received the news in an email:

Nous souhaitons partir sur Seattle pour une durée de trois semaines cet été. Serai ce possible de séjourner chez vous pendant ce temps? Pour la nourriture et le reste on va se débrouiller. Nous attendons votre réponse. (We wish to travel to Seattle for three weeks this summer. Is it possible to stay with you during that time? We can figure out the details about food and other things. We await your response.)

I responded with an enthusiastic Oui!

As I later learned, their friends and families on Huahine had been sceptical about their ability to raise the money needed. But they surprised everyone and made a point of being very nonchalant when they told their families that they had purchased their tickets. They arrived in Seattle in July 2013 for their three-week stay. My husband and I, along with several of the University of Washington students who had traveled to Huahine, were overjoyed to welcome them at the airport. 
I learned that they had been planning the trip for a year, earning the money by selling plates of home-cooked chicken and rice with vegetables - 800 plates in all — which they sold for 500 CFP each (roughly US\$6). Because the university is on the island of Tahiti, they could only make and sell the food when they returned home to Huahine during short breaks from school.

Teana and Moenau decided to come to Seattle because they wanted to see new things and have new adventures, and also to see their American friends from the University of Washington. In addition, they wanted to improve their English (what little they knew they had learned from the American students). From the moment they landed in Seattle they insisted that I speak only English with them.

While here, they enjoyed everything immensely. We spent much of the time together, sharing stories and laughter, planning future trips, and fantasising about American ventures that they could institute on Huahine. While driving them around I could see their curiosity and enthusiasm about things that are commonplace for most Americans. As they said, 'Little things make us very happy'. Such things as yellow school buses, police cars and fire engines - all things they knew only from television - caused great excitement. They called the fraternity and sorority houses near the University of Washington campus 'Harry Potter' houses. They made fun of Americans' love of putting peanut butter in everything, but after discovering Cap'n Crunch's Peanut Butter Crunch they insisted on having it every morning for breakfast (along with blueberry pancakes and other American favourites). Their visit to Seattle's Theo Chocolate factory inspired them to think about developing a cacao plantation on Huahine, and they googled information about planting cacao as soon as they got home that day.

Travelling is important to Teana and Moenau (as well as to many Tahitians). As they told me, they can expand their horizons, learn new things, and make things come to life that they had seen only in movies or on television. They can also make new friends. They wanted to try everything, taste everything, and experience everything. As they kept saying, 'We want to benefit from our visit'.

Towards the end of their visit, as we sat together after dinner telling stories and talking about their experiences, I thought about this publication because I had recently been invited to contribute 
an essay. I explained the idea of the volume to Teana and Moenau, indicating that it might be more interesting if the essay came from them as 'tourists in Seattle', rather than from me. They were delighted at the prospect of collaborating with me on a story for the publication and to 'appear in a book'. We immediately began to sketch out ideas. More focused discussions followed over the next few evenings, as they told me about the things that they enjoyed the most while they were 'tourists in Seattle'. I jotted down their words, translating whenever they switched to French and, eventually (with their approval), I smoothed out the text and provided my own brief commentary (appearing below in italics). Teana and Moenau chose the photos to accompany their stories.

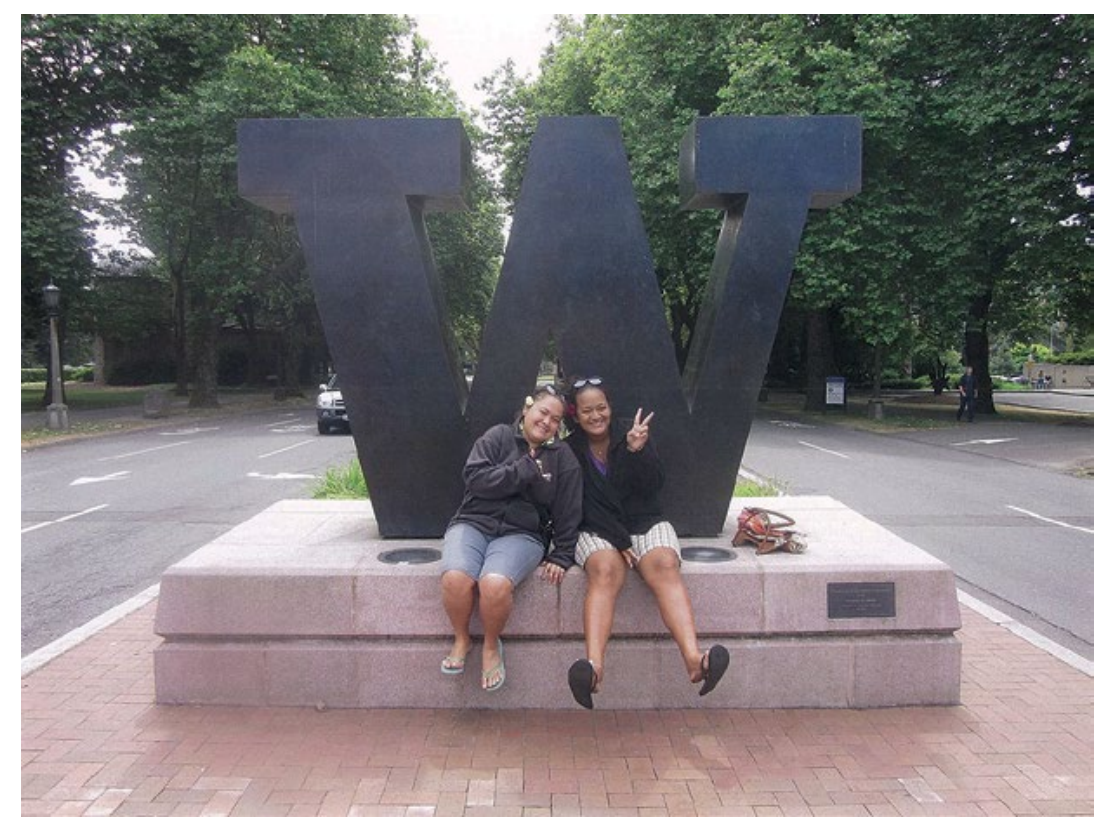

Figure 99. Teana and Moenau at the entrance to the University of Washington.

Source. Photographed by Miriam Khan. 


\section{The Pike Place Market}

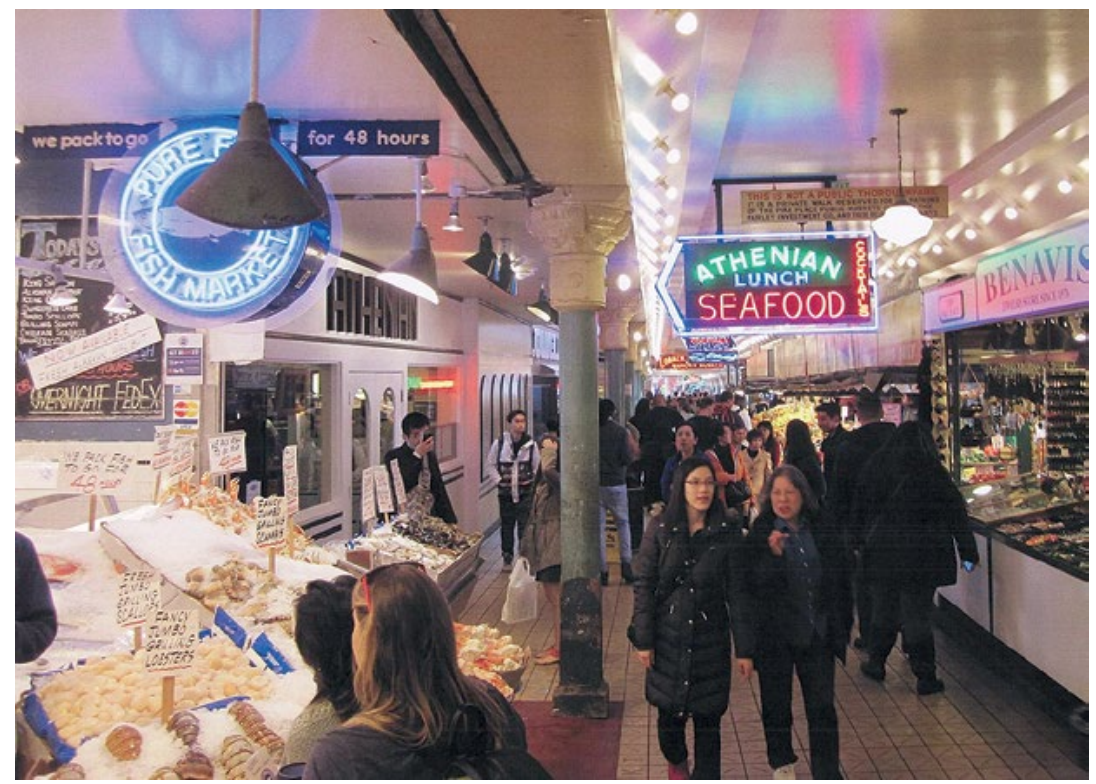

Figure 100. The Pike Place Market.

Source. Photographed by Teana Gooding, 31 July 2013.

'It's very big. There are so many different things at the market. We saw many artists from different countries. We saw people carving in wood and people making jewellery. Here they do a lot of things to attract people to the market. They have people who sing and dance. There are people who toss fish to get your attention. We saw a blind man who played the guitar and a young child who gave him money.'

'Here people are very friendly. When you buy something they ask, "How are you today?" Tahitians are welcoming in some ways, but if they are just doing their job, serving you dinner or selling you something in the market, they don't ask how you are. The vendors in Tahiti just sell you something and tell you the amount you owe them.'

\section{Commentary}

Seattle's Pike Place Market, which opened in 1907, is one of the oldest, continuously operated public markets in the United States. It sits on a hill overlooking, and running parallel to, Seattle's waterfront. When it first 
opened it was used only by farmers selling their produce, but has since grown into one of Seattle's main tourist attractions. Today the market welcomes about 10 million visitors a year.

One of the market's main draws is Pike Place Fish, where an employee stands near the ice-covered fish table and throws large salmon and other fish over the counter to another employee who catches it and prepares it for sale. Although this tradition got started to save employees from having to walk out to the fish table every time someone wanted a fish, it now serves as a major attraction for visitors.

In contrast to the Pike Place Market, the Marché de Pape'ete (Municipal Market), teeming with fresh fish, fruits and vegetables, as well as handicrafts and souvenirs, still serves Pape'ete's urban population, people who may not have access to fishing boats or food gardens. Tourists tend to spend their time on the second storey where the crafts and souvenirs can be found.

\section{Shopping}

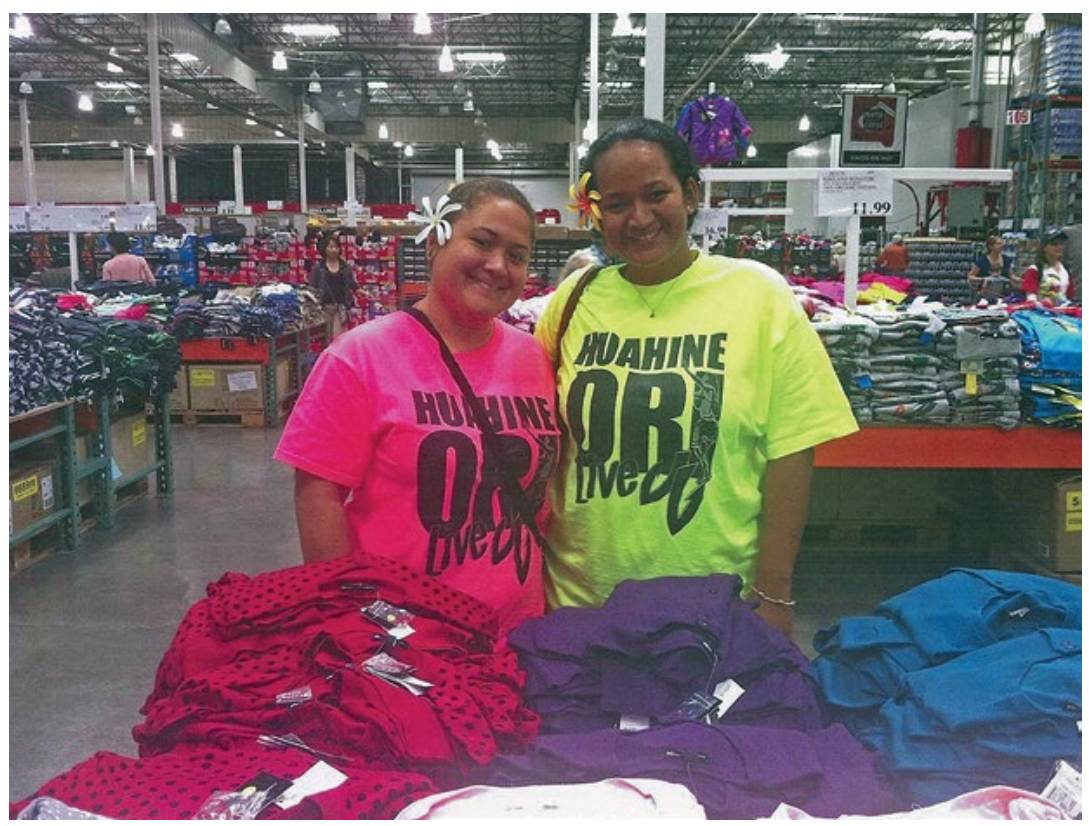

Figure 101. Teana and Moenau at Costco.

Source. Photographed by Miriam Kahn, 30 July 2013. 
'We love to go shopping here! We love the prices. We love the high quality of the clothing. In Tahiti if clothing is cheap it is very poor quality. No regular clothing is produced in Tahiti and everything needs to be imported so it is very, very expensive. Here things are very cheap for us. But then when it comes time to pay they add the tax and it is not as cheap as we had thought. Why don't they just include the tax with the price of the clothing? We like shopping here - the clothing, the styles, the sizes (in Tahiti it is hard to find our sizes), and the many sales!'

\section{Commentary}

There are only a few shops that make Tahitian clothing for sale, usually quite expensive. People typically buy imported clothing or have their clothing made by a seamstress (or make it themselves if they know how). Both Teana's and Moenau's mothers are seamstresses and have a steady stream of customers.

\section{Experience Music Project}

'For us this museum was very interesting. There were lots of things for people to experience and ways they could express themselves. The visitors could try out different instruments. We think that visitors might develop an interest in music. This way there would be fewer problems with drugs later on because they got interested in music.'

\section{Commentary}

Museums in Tahiti, most of which are fairly basic with objects lined up in glass cases, tend to highlight either Tahiti's past or westerners whose fame rests on their adventures and exploits in Tahiti. The main museum is the Musée de Tahiti et ses îles (Museum of Tahiti and its islands), which is a Polynesian ethnographic museum. Other smaller museums include Robert Wan's Black Pearl Museum (attached to a black pearl store), the Paul Gauguin Museum (with relatively poor, small reproductions of some of his paintings), the Seashell Museum (with standard taxonomic exhibits of shells and fish from the lagoon), and the James Norman Hall Home (a replica of the home of the American author of Mutiny on the Bounty that portrays the writer's life in Tahiti and houses his 3,000-book library). 
TOURING PACIFIC CULTURES

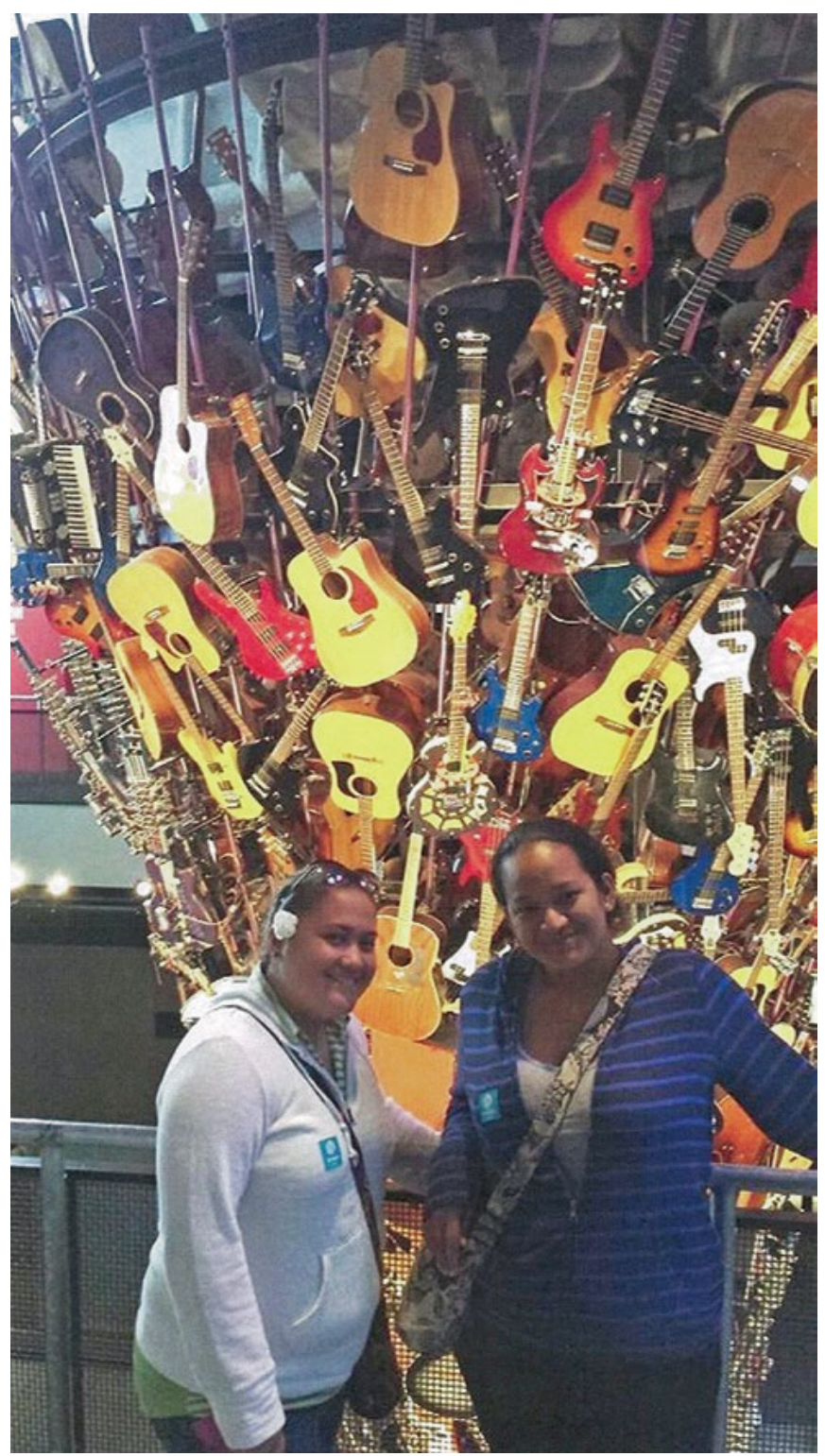

Figure 102. Teana and Moenua at the Experience Music Project.

Source. Photographed by Miriam Kahn, 12 August 2013. 


\section{The Lighthouse for the Blind, visit with Paula}

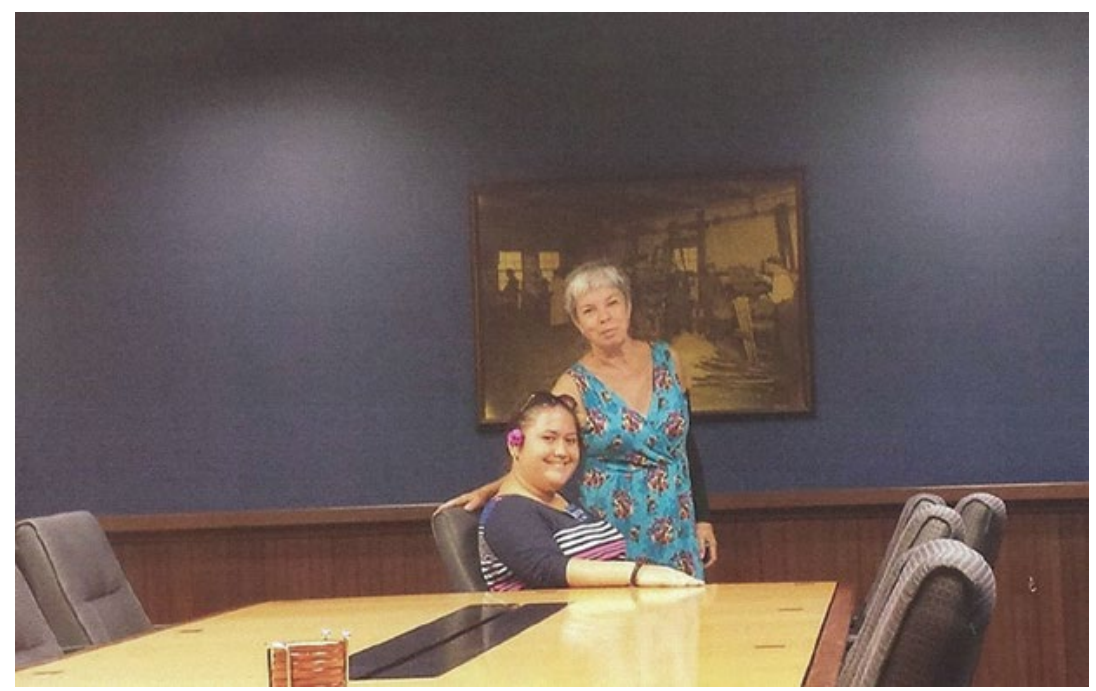

Figure 103. Teana and Paula Hoffman in a conference room at the Lighthouse.

Source. Photographed by Miriam Kahn, 5 August 2013 and used with Paula Hoffman's permission.

'This was the first time we saw blind people working. They were working at very complicated things, making machines and working with very small objects. In Tahiti blind people don't work. The government just provides some money for them for their bus and things like that. They have to make do with very little. Blind people live with their families but are not very happy because they have to depend on their families for everything. Here we could see that they are happy because they can be independent. We were also impressed that here buses have machines to take a person in a wheelchair. They just lower the machine and pick up the person in the wheelchair. We saw that sidewalks have ramps for wheelchairs. We don't have any of that in Tahiti.'

\section{Commentary}

Paula Hoffman, who had been on the study abroad trip in 2010, works at the Lighthouse for the Blind, Inc. Teana and Moenau, both of whom have relatives who are blind, expressed great interest in visiting Paula's place of work. 
Since 1918 the Lighthouse has provided employment and support for people who are blind, deaf-blind, and blind with other disabilities. The Lighthouse trains people in precision machining, where they produce an assortment of machined parts and plastic injection molding for aerospace manufacturers, as well as office products and hydration equipment for the US Government and the US Military.

\section{The Woodland Park Zoo}

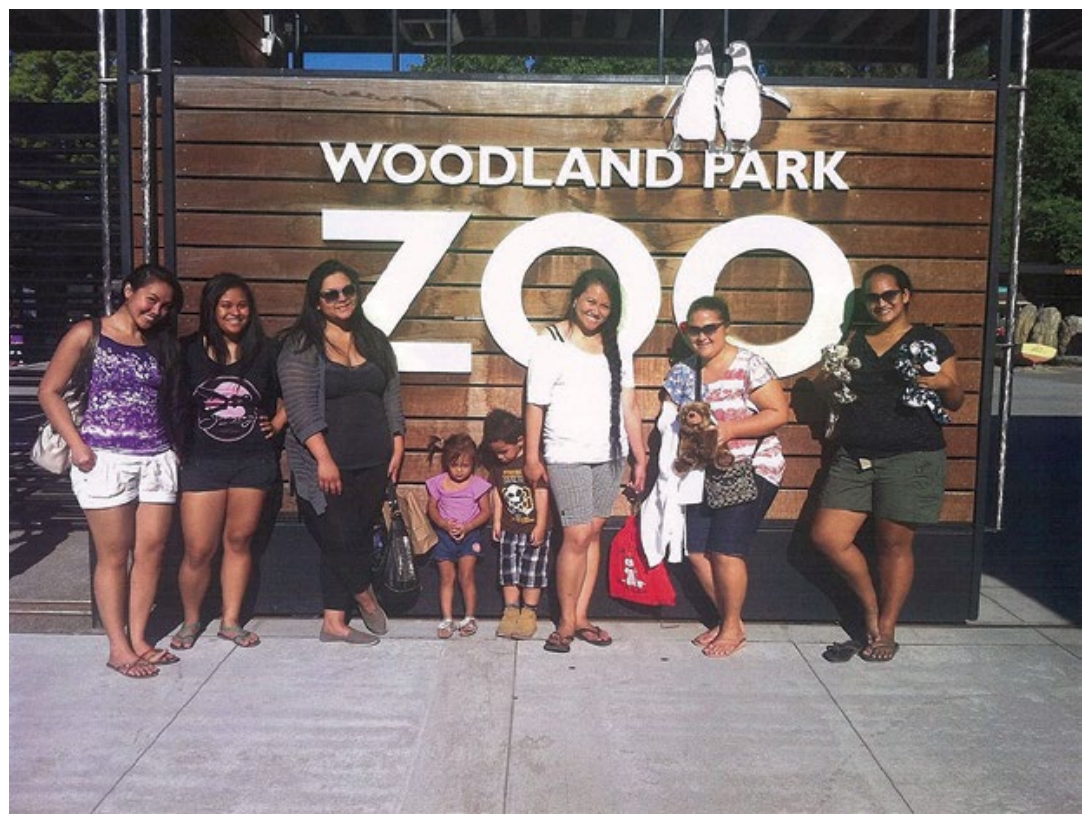

Figure 104. Left to right: Helen Enguerra, Theresa Enguerra, Desiree Bungay, Anaiyah Johnson, Joash Tupufia, Savali Tupufia, Teana and Moenau at the Woodland Park Zoo.

Source. Photographed by Miriam Kahn, 7 August 2013 and used with everybody's permission.

'We were able to see animals that we had only seen in films and in nature programs on TV. It brought us back to our childhood and how when we were little there were many animals we wanted to see but we couldn't. We only saw them in the cartoons. When we were in the zoo we could see the real animals. They were the way we had imagined they would be. We were excited most to see the lions, the penguins and the snakes. We don't have snakes in Tahiti.' 


\section{Commentary}

The trip to the zoo included two former University of Washington students (Helen and Desiree), who had gone to Huahine in 2010, as well as Helen's sister (Theresa) and cousin (Savali), and their children. There are no zoos in French Polynesia.

\section{Baseball game-Seattle Mariners vs Milwaukee Brewers}

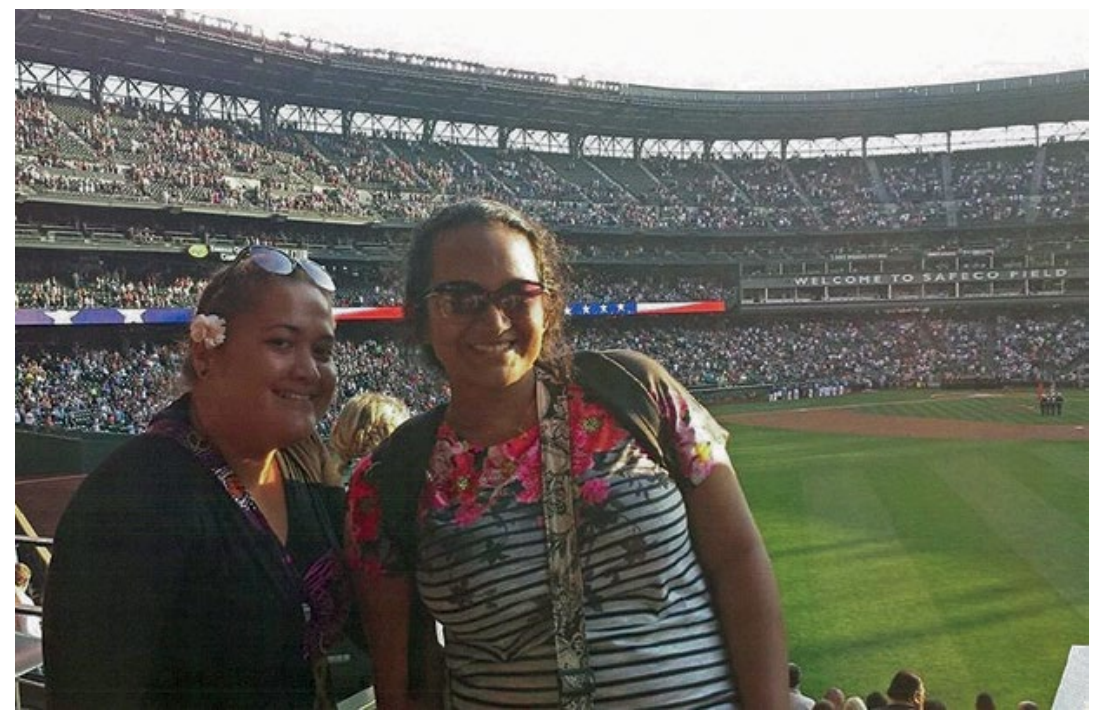

Figure 105. Teana and Moenau at the Mariners vs Brewers game at Safeco Field.

Source. Photograhed by Miriam Kahn, 11 August 2013.

'The baseball game was very amazing! The stadium was very big with lots of people! It was just like we had seen in the movies. But now we saw it in real life. And now we can understand the game and how it is played. The big screen was so big. There's a cameraman taking pictures of the spectators and then he puts those pictures on the big screen. But he didn't take pictures of us. When we got out of the train on our way to the baseball game there were so many people all streaming towards the stadium. That was so strange.' 


\section{Commentary}

In French Polynesia the national sport is va'a (outrigger canoe racing), for which Tahitian teams consistently break world records. Other sports include rugby, basketball, soccer and surfing. Baseball does not exist. Seattle's Safeco Field, with a seating capacity of over 54,000, holds (when full) more than 10 times the number of people who live on the island of Huahine.

\section{Disco dancing at Tia Lou's}

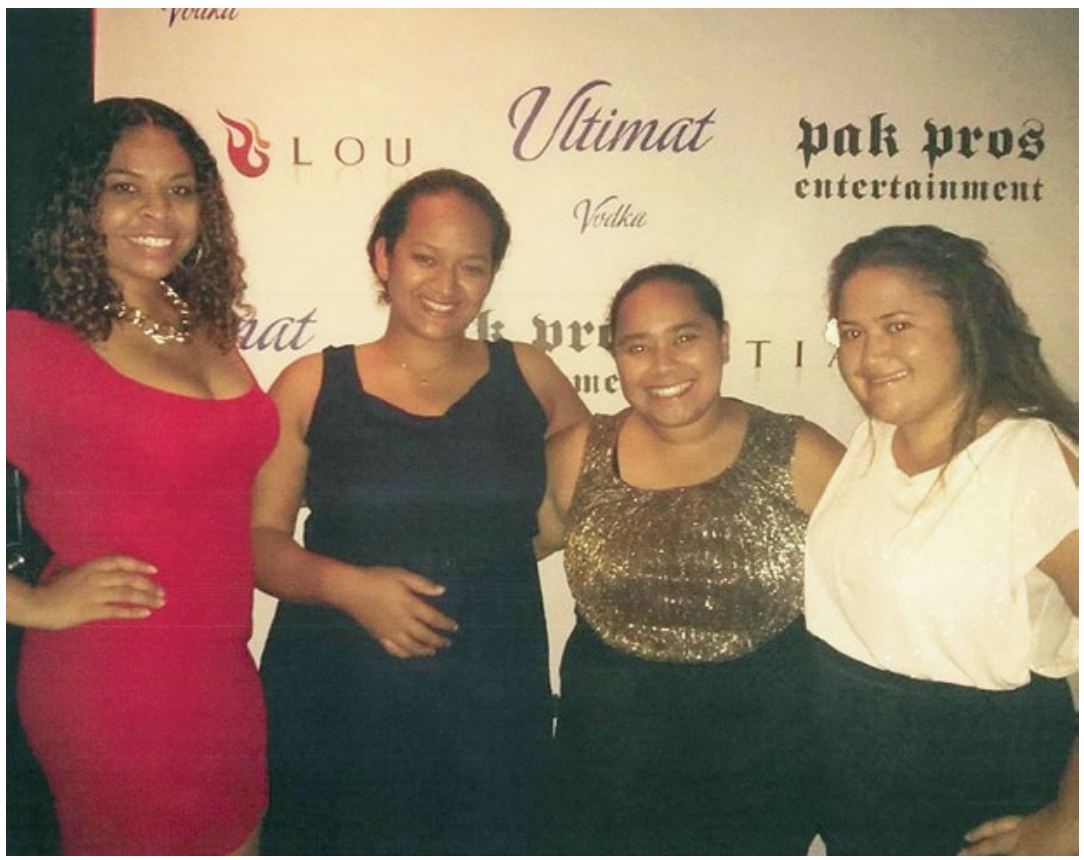

Figure 106. Natalie Hart, Moenau, Ashley Bird, Teana at Tia Lou's Lounge. Source. Photographed by Miriam Kahn, 15 August 2013 and used with their permission.

'At the disco we noticed that all the African-American people were dancing in one area with their own DJ, and everyone else was dancing in a different area. That was strange for us. In Tahiti the Tahitians and the French disagree about political things but there is no segregation. The French people act proud because they feel superior that they are "helping" us Tahitians but we can be together with them. No problem.' 


\section{Commentary}

Natalie Hart, who had stayed with Teana's family in 2010, and Ashley Bird, who had stayed with them in 2012, were the 'tour guides' for the disco evening. In spite of what many people say about the diversity of Seattle, Teana and Moenau noticed that there is still a lot of economic, social and racial segregation.

\section{Umoja Festival}

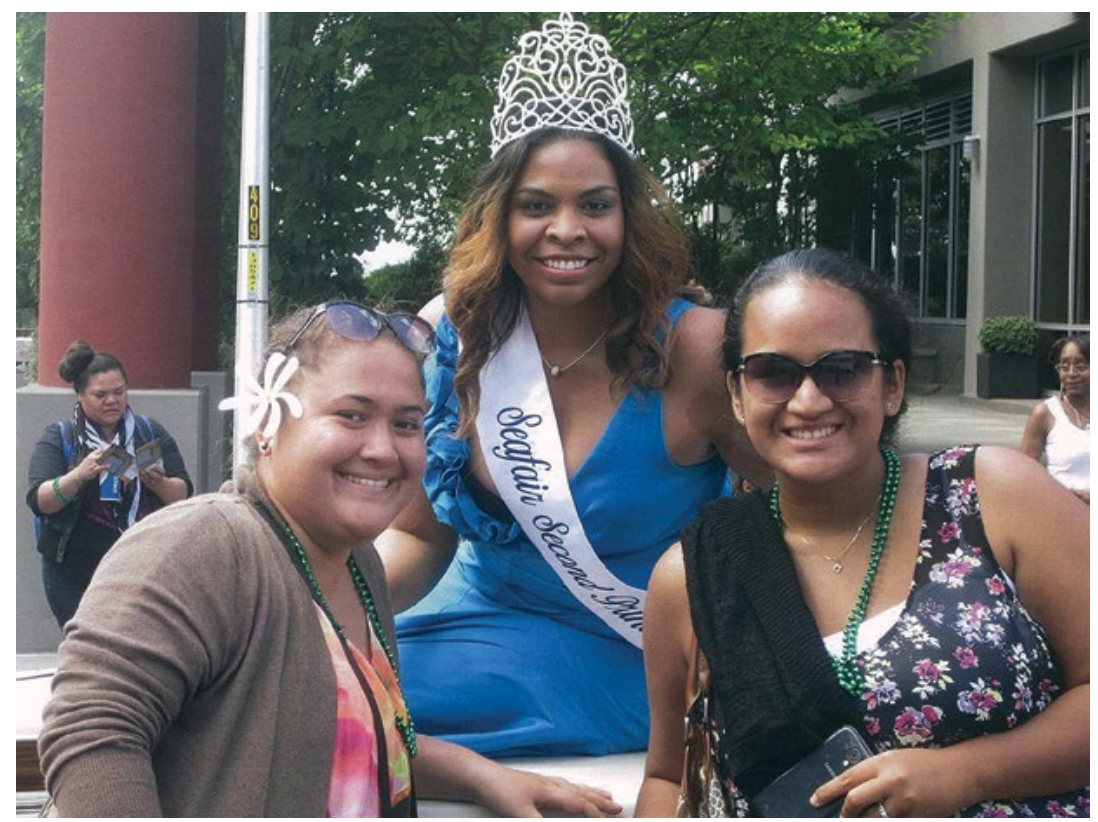

Figure 107. Teana, Natalie Hart and Moenau at the Umoja Festival.

Source. Photographed by Miriam Kahn, 3 August 2013 and used with their permission.

'We liked the festival where our friend, Natalie, was the queen. We liked that African-American people have a festival just for themselves. It was interesting to learn about Trayvon Martin and how the people brought attention to his case in the festival. We saw that there is still a lot of discrimination here. We could see this in people's eyes.' 
'We liked the parade with all the colourful and sparkly costumes and the dancing. We liked the showy way the people walked and danced. We were happy to see Natalie go by in the parade. Natalie later told us that when she heard us call her name as she went by it made her very happy and made her feel important that her two Tahitian friends had come to the festival to see her. One thing was difficult for us-when the African-American people talk it is hard for us to understand their English.'

\section{Commentary}

The Umoja Festival is part of Seafair, which is Seattle's annual, monthlong summer festival then in its 64th year. Seafair includes community events, parades, drill team marches, a torchlight run, a milk carton derby, pirates and clowns, air shows, and hydroplane and other boat races.

A highlight of the Seafair festival is the Miss Seafair contest, which over the years has come to celebrate the diversity of the greater Seattle area. The Seafair Scholarship Program for Women, for example, has evolved into one that rewards academic ambition, celebrates diversity, and highlights future leaders. The Miss Seafair contestants represent various neighbourhoods and ethnic communities in Seattle. Natalie Hart, who stayed with Teana's family in 2010, was the second runner-up for Miss Seafair 2013, as well as the Queen of the UmojaFest (African-American festival).

The Umoja (a Swahili word meaning 'unity') Festival has been the most unifying celebration in Seattle's African-American community for decades. The parade is just one of many events over a three-day weekend. Numerous religious, educational and civic associations participate in the parade. 
This text is taken from Touring Pacific Cultures, edited by Kalissa Alexeyeff and John Taylor, published 2016 by ANU Press, The Australian National University, Canberra, Australia. 